\title{
水素結合性小分子による核酸塩基認識と一塩基多型蛍光検出
}

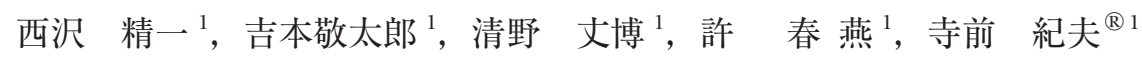

\section{Nucleobase recognition by hydrogen bond forming ligands and its use for fluorescence detection of single-nucleotide polymorphisms}

\author{
Seiichi Nishizawa ${ }^{1}$, Keitaro Yoshimoto ${ }^{1}$, Takehiro Seino ${ }^{1}$, \\ Chun-Yan $\mathrm{XU}^{1}$ and Norio TeramaE ${ }^{1}$ \\ ${ }^{1}$ Department of Chemistry, Graduate School of Science, Tohoku University, Aramaki, Aoba-ku, Sendai-shi, \\ Miyagi $980-8578$
}

(Received 6 January 2004, Accepted 5 February 2004)

\begin{abstract}
In combination with abasic site (AP site)-containing oligodeoxynucleotides (ODNs), we demonstrate the potential use of hydrogen bond-forming ligands, 2-amino-7-methyl-1,8-naphthyridine (AMND) and 2-amino-4-oxopteridine (pterin), for the recognition of nucleobases in the aqueous phase. Our strategy is based on the construction of an AP site in ODN duplexes, which allows small synthetic and/or biotic ligands to strongly bind to target nucleobases; an AP site-containing ODN is hybridized with a target ODN so as to place the AP site toward a target nucleobase, by which hydrophobic microenvironments are provided for ligands to recognize target nucleobases through hydrogen-bonding. From an examination of the binding behaviors by melting temperature $\left(T_{\mathrm{m}}\right)$, fluorescence and circular dichroism spectra measurements, it has been found that AMND selectively binds to a cytosine base with a $1: 1$ binding constant of $>10^{6}$ $\mathrm{M}^{-1}$, while pterin shows selectivity for a guanine base $\left(K_{11}=1.2 \times 10^{4} \mathrm{M}^{-1}\right)$ over other nucleobases. The observed high stabilities of $1: 1$ complexes can be explained by a cooperative binding event, i.e., hydrogen-bonding with target nucleobases and stacking with nucleobases flanking the AP site. The potential use of these ligands is also presented for the fluorescence detection of single-nucleotide polymorphisms (SNPs) of the cancer repression gene p53.
\end{abstract}

Keywords : ligand; hydrogen bond; stacking; abasic site; fluorescence detection; nucleobase ; single-nucleotide polymorphism.

\section{1 諸 言}

生体中における特異的な分子間相互作用や生体高分子の 構造維持に, 水素結合が果たす役割は広く知られている. なかでも DNA の特異的塩基対形成に水素結合が必要であ ることは周知の事実で, DNA が遺伝情報の担い手として 正確に複製，あるいは転写されるのは，まさに水素結合を 介した相補的塩基対形成に起因している.

一般に，水素結合は弱い相互作用と考えられがちである が, 分子間力としては比較的強く $\left(10 \sim 40 \mathrm{~kJ} \mathrm{~mol}^{-1}\right)$, 本

\footnotetext{
${ }^{1}$ 東北大学大学院理学研究科化学専攻: 980-8578 宮城県仙台市 青葉区荒巻字青葉
}

質的には静電相互作用を主とするものである ${ }^{1)}$. また水素 結合の重要な特徵は結合の方向性を示すことで，このこと がタンパク質や核酸などの巨大分子構造を決める上で特に 重要となる.

このような水素結合の特色は，分析試薬を設計する際に 大きな魅力であり，精密な分子認識を達成するための不可 欠な相互作用の一つと見なすことができる．標的基質に合 致した分子間相互作用を選択する必要があることはいうま でもないが，特に核酸塩基類をターゲットとする場合，選 択性発現のために水素結合形成をベースとする試薬設計を 行うことは，ごく自然なアプローチといえる．実際，DNA 中での核酸塩基間の分子認識のモデル系として多くの報告 


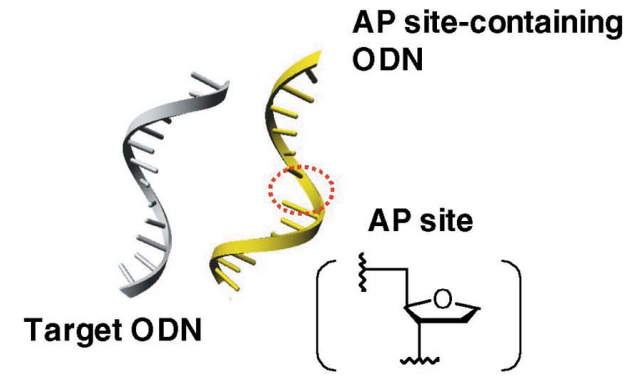

\section{Hybridization with an AP site- containing ODN}

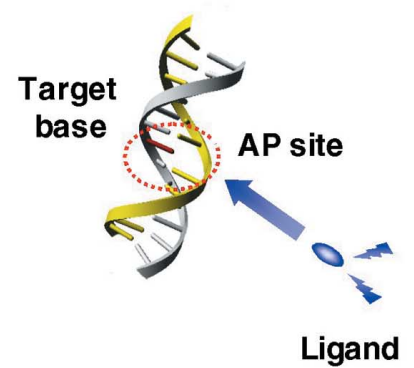

\section{Selective binding \& Signaling at the AP site}

Fig. 1 Schematic illustration of nucleobase recognition by hydrogen bond forming ligands, in combination with an abasic site (AP site)-containing oligodeoxynucleotide (ODN) duplex

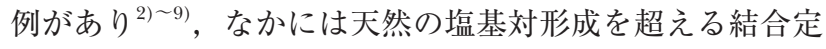
数や選択性を発現する合成化合物も報告されている。しか しながら，これらの化合物の特異性が発現するのは有機溶 媒中に限られており, 分析試薬として完全水系へ適用する ことは極めて困難な状況にあった．例えば，J. Rebeck, Jr. らは ${ }^{6)}, 1$ 分子の中に水素結合部位や電荷相互作用部位, 更にスタッキング相互作用部位を組み入れた，いわば合成 的アプローチの完成型とも見なせるレセプターを報告して いるが, 水中におけるサイクリック AMP (adenosine 2',3'-cyclic monophospate) との 1: 1 結合定数は, わずか $660 \mathrm{M}^{-1}(I=0.05 \mathrm{M})$ にすぎない.これは，水和により 水素結合形成が著しい妨害を受けるためで，ここに水素結 合形成を主な駆動力とする合成小分子の大きな限界が存在 していた.

一方，DNA あるいはRNA を有機小分子に対する分析試 薬として利用する試みがある ${ }^{10) \sim 13)}$ 。これらの機能性核酸 は, アプタマー (aptamer) と名付けられ ${ }^{10)}$, アミノ酸 ${ }^{12)}$ やATP (adenosine 5'-triphospate) ${ }^{13)}$ に特異的に結合する ものなど, 多くの報告例がある. また最近では, 水素結合 性の小分子リガンド（ナフチリジン誘導体）により DNA 二重鎖のバルジ構造 ${ }^{14) 15)}$ やミスッチ構造 ${ }^{16) ~ 18) ~}$ うることが中谷らにより報告された.これら一連の結果は, DNA二重鎖が水素結合を機能させる疎水場環境を有機小 分子に提供することを強く示唆するものである。つまり, DNA二重鎖が形成する特異的な高次構造を「分析反応場」 としてうまく利用すれば，合成小分子による核酸塩基認識 が可能になると期待できる.

本論文では，分析反応場として DNA 脱塩基部位（AP sites, apurinic/apyrimidinic sites）を利用する水素結合性 小分子による核酸塩基認識，並びにこれを一塩基多型 (SNPs, single nucleotide polymorphisms) の蛍光検出に 適用した著者らの研究結果 ${ }^{19) \sim 21)}$ を紹介する.
2 実験

\section{$2 \cdot 1$ 試 薬}

AMND (2-amino-7-methyl-1,8-naphthyridine）は既報 ${ }^{22)}$ に従い合成した.プテリン（2-amino-4-oxopteridine）は 市販品（和光純薬製，特級）をそのまま用いた.オリゴデ オキシヌクレオチド（ODN）はカスタム合成（日本遺伝 子研究所製）したものを用い，その濃度は $260 \mathrm{~nm}$ におけ るモル吸光係数から算出した ${ }^{23)}$. 純水は, 一次蒸留水 (Autostill WX 710，ヤマト科学製）を Mill-Q Labo システ ム (ミリポア製) で処理した超純水 $(18.2 \mathrm{M} \Omega$, 全有機炭 素： 5 ppb 以下）を用いた。 その他の試薬は, 市販の特級 試薬をそのまま使用した。

\section{$2 \cdot 2$ 装置及び測定条件}

ODN 融解温度 $\left(T_{\mathrm{m}}\right)$ 測定は, 光路長 $1.0 \mathrm{~mm}$ の石英セ ルを用い, Ultraspec 3300pro 分光光度計（アマシャムバ イオサイエンス製）で測定した。得られた融解曲線を MeltWin ${ }^{24)}$ により解析し， $T_{\mathrm{m}}$ 值を算出した。また，蛍光 スペクトルは, FP-777W 分光蛍光光度計（日本分光製） あるいは RF-5300PC 分光蛍光光度計（島津製）で測定し た. CD (circular dichroism) スペクトル測定には，J-820 円二色性分散計（日本分光製）を使用した。なお，いずれ の測定においても，ODN を含む試料溶液はアニーリング したものを用いた。

3 本系の検出原理：脱塩基部位と水素結合性リガ ンド

本研究で提案する DNA 脱塩基部位を利用する核酸塩基 認識の概念図を Fig. 1 に示す。脱塩基部位は生体内にお ける塩基除去修復過程の中間体として生成することが知ら れているが25), 本研究では DNA二重鎖中に意図的に構築 


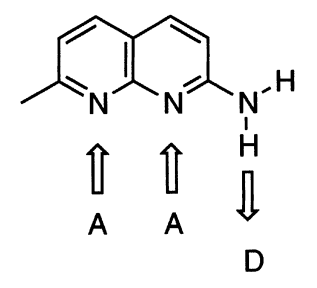

AMND

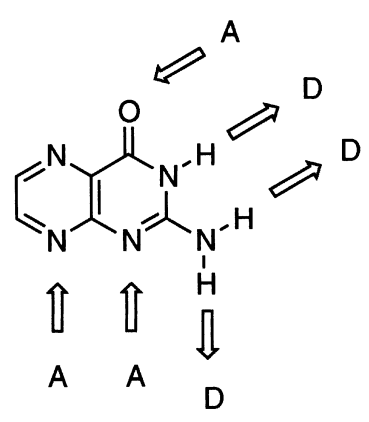

pterin
Fig. 2 Structures of fluorescence ligands used in the present study

AMND : 2-amino-7-methyl-1,8-naphthyridine; pterin : 2-amino-4-oxopteridine; A: hydrogen bond acceptor; $\mathrm{D}$ : hydrogen bond donor

する。つまり，標的塩基を含む一重鎖 DNA と脱塩基部位 を有する一重鎖 DNA をハイブリダイゼーションさせるこ とで標的塩基の向側に疎水場空間を構築させた後, 同空間 中において水素結合性リガンドとの錯形成を行うというも のである. 蛍光性の小分子リガンドを利用することによ り, 標的塩基選択的な核酸塩基認識反応を蛍光シグナル変 化として簡便かつ迅速に検出できると期待される.

上述した検出システムを達成するためのリガンドとして 種々の試薬設計が考えられるが, 少なくとも, (1) 核酸塩 基選択性を発現しうる水素結合部位を有していること，(2) 蛍光性であること, かつ, (3) 水溶性であることが必要で ある．著者らは，これらの要件を満たす有機化合物として AMND 及びプテリンに着目した（Fig. 2).

AMND は䖝光性のナフチリジン誘導体で（ $\mathrm{pH} 7$, 励起 $\lambda_{\max } 353 \mathrm{~nm}$, 蛍光 $\left.\lambda_{\max } 405 \mathrm{~nm}\right)$, シトシンと同様の水素 結合様式 (DAA, D : 水素結合ドナー; A: 水素結合アクセ プター）を有する。これまでに，2-amino-1,8-naphthyridine を基本骨格とする種々の試薬合成並びに有機溶媒中 における核酸誘導体との錯形成挙動が報告されている。 ま た，諸言で述べたように，中谷らは2-amino-1,8-naphthyridine 誘導体がバルジ塩基やミスマッチ塩基対認識に

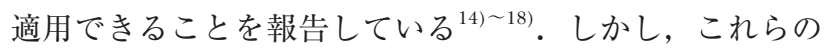
誘導体では，アミノ基がアシル化されているために蛍光性 が著しく損なわれており, 蛍光試薬として利用するために は，本系のようにアミン構造を維持することが肝要であ $ろ^{26)}$.

また，プテリンは葉酸やビオプテリンなどの構成成分 で，これらの分解物として尿中に排出される蛍光性化合物

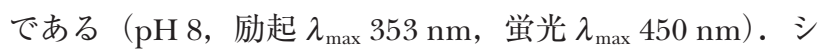
トシンあるいはグアニンと同様の水素結合様式（DAA あ るいは DDA）を有していることから, 核酸塩基類似化合
物として人工ヌクレオシド合成 ${ }^{27)}$ に利用されているほか,

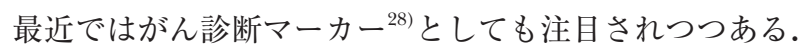

一方, 脱塩基部位についても多彩な構造設計が可能であ る.ここでは, 化学的安定性並びに系のシンプル性を特に 考慮し, 単に塩基部分が脱離したデオキシリボース構造 (dspacer, Fig. 1 参照) を用いた。

\section{4 脱塩基部位における核酸塩基認識}

\section{4・1 AMND の認識機能評価}

著者らはまず, ODN 融解温度 $\left(T_{\mathrm{m}}\right)$ 測定により AMND と核酸塩基との相互作用を評価した。完全相補な ODN 二重鎖と比べて脱塩基部位（AP site）を含む二重鎖 では，その熱力学的安定性が著しく低下することが知られ ているため, AMNDの AP siteへの挿入の有無を $T_{\mathrm{m}}$ 值の 変化として評価できるはずである。つまり, AMND が AP site へ挿入するならば， $T_{\mathrm{m}}$ 值の増加が期待される。本研 究では, AP site が ODN 二重鎖の中央に位置するように 設計したモデル ODN 二重鎖（5'-TCCAGXXGCAAC-3' / 3'AGGTCYYCGTTG-5', $\underline{X}=$ dSpacer, $\underline{Y}=\mathrm{G}, \mathrm{C}, \mathrm{A}, \mathrm{T})$ と AMND との相互作用を評価した。また，比較のために， AP site を含まない ODN 二重鎖との相互作用も評価した。

まず，AMND 添加による完全相補な ODN 二重鎖（5'TCCAGZZGCAAC-3' / 3'-AGGTCYCGTTG-5', $\underline{Z}, \underline{Y}=$ G, C, $\mathrm{A} ， \mathrm{~T} ）$ の $T_{\mathrm{m}}$ を測定したところ，有為な変化は観測され なかった，例えば，AMND 添加による5'-TCCAGGGCAAC3'/3'-AGGTCCCGTTG-5' 二重鎖の $T_{\mathrm{m}}$ 值の変化はわずか + $0.3^{\circ} \mathrm{C}$ にすぎず, AMND 添加前後における $T_{\mathrm{m}}$ は実験誤差 範囲内で一致する。このことから AMND は, 多くの多環 芳香族化合物（エチジウムブロマイドなど）で見られるよ うな塩基対間への挿入，いわゆるインターカレーション等 により，完全相補な二重鎖とは相互作用しないものと考え られる。一方，次に述べるように，脱塩基部位を含む ODN 二重鎖では， $T_{\mathrm{m}}$ 值の顕著な増加が観測された。

Table 1 に, AMND 添加による AP site 含有モデル二重 鎖（5'-TCCAGㅍGCAAC-3' /3'-AGGTCYCGTTG-5'， $\underline{X}=$ dSpacer, $\underline{Y}=\mathrm{G}, \mathrm{C}, \mathrm{A}, \mathrm{T})$ の融解温度 $\left(T_{\mathrm{m}}\right)$ 変化を示 す. AMND 添加により $T_{\mathrm{m}}$ 值が著しく増加していること が分かる. 標的塩基がシトシンの場合, $\Delta T_{\mathrm{m}}$ 值は $+13.4^{\circ} \mathrm{C}$ にも達しており, $\Delta T_{\mathrm{m}}\left({ }^{\circ} \mathrm{C}\right)$ 值の序列は, $\mathrm{A}(+2.9)<\mathrm{G}$ $(+5.0)<\mathrm{T}(+10.9)<\mathrm{C}(+13.4)$ である. AP site を含ま ない完全相補二重鎖ではこのような $T_{\mathrm{m}}$ 值の増加が見られ ないことから, AMNDがAP siteへ取り达まれていること は明らかである. 更に, $\Delta T_{\mathrm{m}}$ 值が一様ではなく標的塩基 に大きく依存していることから，AMND がシトシンと選 択的に錯形成していること，すなわち核酸塩基に対する認 識機能の発現が示唆される.

AMND と核酸塩基との相互作用を, 更にCD スペクト 
Table 1 Melting temperatures of AP site-containing ODN duplexes in the absence $\left(T_{\mathrm{m}(-)}\right)$ and presence $\left(T_{\mathrm{m}(+)}\right)$ of hydrogen-bonding ligands ${ }^{\text {a) }}$

\begin{tabular}{|c|c|c|c|c|}
\hline \multirow{2}{*}{\multicolumn{3}{|c|}{ 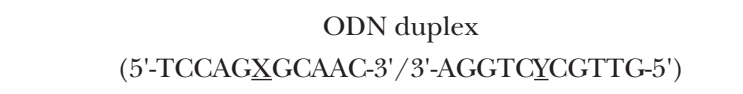 }} & \multicolumn{2}{|c|}{ Hydrogen-bonding ligands } \\
\hline & & & \multirow{2}{*}{$\begin{array}{c}\text { AMND } \\
T_{\mathrm{m}(+)}\left(\Delta T_{\mathrm{m}}\right) /{ }^{\circ} \mathrm{C}\end{array}$} & \multirow{2}{*}{$\begin{array}{c}\text { Pterin } \\
T_{\mathrm{m}(+)}\left(\Delta T_{\mathrm{m}}\right) /{ }^{\circ} \mathrm{C}\end{array}$} \\
\hline $\mathrm{X}$ & $\mathrm{Y}$ & $T_{\mathrm{m}(-)} /{ }^{\circ} \mathrm{C}$ & & \\
\hline$\xi$ & G & $34.8 \pm 0.4$ & $39.8 \pm 0.2(+5.0)$ & $37.5 \pm 0.2(+2.7)$ \\
\hline$\xi$ & $\mathrm{C}$ & $31.6 \pm 0.6$ & $45.0 \pm 0.2(+13.4)$ & $32.5 \pm 0.4(+0.9)$ \\
\hline & A & $34.4 \pm 0.1$ & $37.3 \pm 0.2(+2.9)$ & $34.5 \pm 0.2(+0.1)$ \\
\hline ans & $\mathrm{T}$ & $29.5 \pm 0.2$ & $40.4 \pm 0.2(+10.9)$ & $30.4 \pm 0.1(+0.9)$ \\
\hline
\end{tabular}

a) [ODN duplex]: $30 \mu \mathrm{M}$; [AMND]: $580 \mu \mathrm{M}$; [pterin]: $290 \mu \mathrm{M}$. pH: 7.0 adjusted by 10 mM sodium cacodylate buffer containing $100 \mathrm{mM} \mathrm{NaCl}$ and $1.0 \mathrm{mM}$ EDTA. Data are given as averages of at leat four measurements.

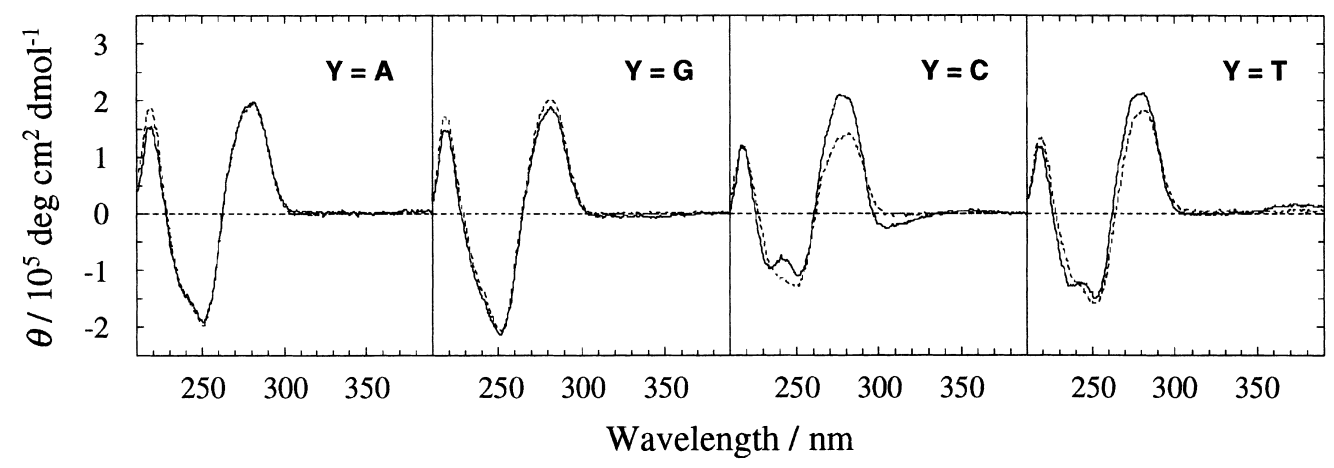

Fig. $3 \mathrm{CD}$ (circular dichroism) spectra of AP site-containing ODN duplexes (5'-TCCAG $\underline{X} G-$ CAAC-3' /3'-AGGTC $\underline{Y C G T T G-5 ', ~} \underline{\mathrm{X}}=\mathrm{dSpacer}, \underline{\mathrm{Y}}=\mathrm{A}, \mathrm{C}, \mathrm{G}, \mathrm{T}$ ) in the absence (broken curve) and in the presence (solid curve) of AMND

[AMND] : $72.5 \mu \mathrm{M}$; [ODN duplex] : $30 \mu \mathrm{M}$ in $10 \mathrm{mM}$ sodium cacodylate buffer solution (pH 7.0) containing $100 \mathrm{mM} \mathrm{NaCl}$ and $1.0 \mathrm{mM}$ EDTA

ル測定により検討した. Fig. 3 に示したように，標的塩基 がプリン塩基（A， G）の場合にはスペクトル変化が見ら れないのに対し，ピリミジン塩基（C， T）の場合にはス ペクトル変化が見られることが分かる。特に標的塩基がシ トシンの場合, AMND 添加により ODN 由来の CD 強度 $(280 \mathrm{~nm})$ が顕著に増加しており, 二重鎖構造の秩序性が 増していることが示唆される。また， $240 \mathrm{~nm}$ 付近及び $300 \sim 400 \mathrm{~nm}$ には, AMND に帰属される誘起 CD バンド が見られることから, AMNDの AP site 空間への挿入が示 唆される. 以上の結果は, $T_{\mathrm{m}}$ 測定の結果とよく対応して おり, AMND がシトシン選択性を示すことを強く示唆し ている.

以上の結果を踏まえて, AP site 空間における AMND と シトシンとの錯形成挙動をより詳細に検討した。AP site

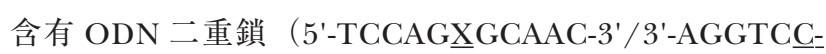
CGTTG-5', $\underline{x}=\mathrm{dSpacer})$ の $T_{\mathrm{m}}$ の, AMND 濃度依存性を 検討したところ，ODN 二重鎖に対して AMND が一当量 存在する場合に $T_{\mathrm{m}}$ の増加がほぼ飽和することが分かっ た. 同様に, ODN二重鎖由来の CD スペクトル変化も AMND が一当量存在する場合に飽和を示した。これらの
結果は, AP site 空間において AMND とシトシンが $1: 1$ 錯体を形成していることを示唆するもので, CD 強度 $(280 \mathrm{~nm})$ 変化から算出した $1: 1$ 錯形成定数は, $1.0 \times$ $10^{6} \mathrm{M}^{-1}$ 以上にも達することが分かった。

蛍光分光法による検討もまた，AMND とシトシンが非 常に強力な $1: 1$ 錯体を形成していることを示唆するもの であった。AMNDは，AP siteを含まない完全相補な ODN 二重鎖には全く蛍光スペクトル変化を示さないのに 対 し, AP site含有二重鎖（5'-TCCAGXXGCAAC-3'/3'AGGTCCCGTTG-5'， $\underline{X}=\mathrm{d}$ Spacer）に対して著しい蛍光 消光を示す（Fig. 4). また，Fig. 4 に示したように， AMND の蛍光は一当量の ODN 二重鎖の存在下でほぼ完 全に消光していることが分かる. 以上のことから, AP site において AMND とシトシンが $1: 1$ 錯体を形成している こと，更に非線形フィッティングにより，その錯形成定数 が $1.0 \times 10^{6} \mathrm{M}^{-1}$ 以上であることが結論付けられる.

ここで, $1.0 \times 10^{6} \mathrm{M}^{-1}$ 以上という $1: 1$ 結合定数は, 合 成小分子試薬で達成した完全水中での核酸塩基認識として 特筆に值する。このような強力な結合定数が得られるの は，本系における核酸塩基認識反応が，AMND/シトシン 


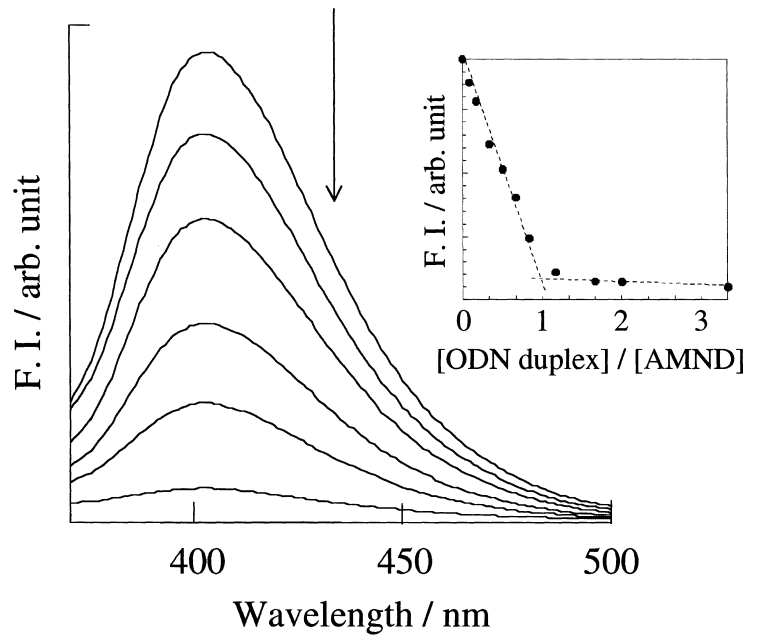

Fig. 4 Fluorescence spectra of AMND $(30 \mu \mathrm{M})$ in the presence of AP site-containing ODN duplex (5'-

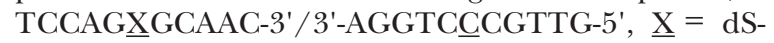
pacer). $\mathrm{pH}=7.0$ adjusted by $10 \mathrm{mM}$ sodium cacodylate buffer containing $100 \mathrm{mM} \mathrm{NaCl}$ and $1.0 \mathrm{mM}$ EDTA

Excitation wavelength: $355 \mathrm{~nm}$. Inset: Fluorescence intensities of AMND $(30 \mu \mathrm{M})$ at $405 \mathrm{~nm}$ in a titration with AP site-containing ODN duplex (5'-TCCAG $\underline{X}$ CAAC-3' / 3'-AGGTCCCGGTTG-5', $\underline{X}=$ dSpacer).

間の水素結合形成（Fig. 5 参照）だけでなく, AP site 上 下に位置する隣接塩基とのスタッキングによる協同的効果 によって達成されているためであると考察している。これ は, DNA 構造の安定化における疎水性相互作用, つまり 構成塩基間のスタッキング相互作用の役割とよく類似して おり, AP site 空間において AMND が，あたかも構成塩基 のように挙動しているものと考えられる.

また，AP siteにおける核酸塩基認識反応のもう一つの 特色は, AMND がグアニンではなくシトシンに選択性を 示す点である. Fig. 5 に示したように，AMNDはグアニ ン及びシトシンとそれぞれ三点及び二点水素結合形成をし ているものと考えられるが，1:1 錯形成定数は, それぞ れ $2.0 \times 10^{4} \mathrm{M}^{-1}$ 及び $1.0 \times 10^{6} \mathrm{M}^{-1}$ 以上であり，二点しか 水素結合を形成しえないシトシンと, より安定な錯体を形 成する。この結果は, 本系における核酸塩基選択性の発現 が, 水素結合以外の他の因子, 例えば, 空間的規制や前述 したスタッキング相互作用によっても支配されていること を示唆するものである. 実際, 分子力学計算による錯体構 造の検討によると, シトシンと錯形成する場合には, AMND が AP site 上下の塩基ときれいに積重（スタッキン グ）していることが示唆された（Fig. 6A）。これに対し， Fig. 6B に示したように，グアニンと錯形成する場合には， AP site 上下の塩基との積重が不完全なものとなっている ことが分かる.このような錯体構造の違いは, おそらく空<smiles>CCn1cnc2c(=O)n3c(nc21)N[CH]Nc1ccc2ccc(C)n(c1-2)[C@H]3C</smiles><smiles></smiles>

Fig. 5 Possible binding structures of the $1: 1$ complex between AMND and guanine $(\mathrm{G})$ or cytosine $(\mathrm{C})$ bases

間的な規制に起因するものと思われるが，現在， ${ }^{1} \mathrm{H}$ NMR や ${ }^{15} \mathrm{~N} \mathrm{NMR}$ 分光法, あるいは X 線結晶構造解析などを用 いたより詳細な検討を進めている.

\section{$4 \cdot 2$ プテリンの認識機能評価}

AMND の場合と同様に, プテリンの認識機能を評価し た. Table 1 に，プテリン添加による AP site 含有 ODN

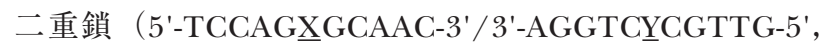
$\underline{\mathrm{X}}=\mathrm{d}$ Spacer, $\underline{\mathrm{Y}}=\mathrm{G}, \mathrm{C}, \mathrm{A}, \mathrm{T})$ の融解温度 $\left(T_{\mathrm{m}}\right)$ 変化 を示す. $T_{\mathrm{m}}$ の増加値は, $\mathrm{AP}$ site 向側の標的塩基に依存し ており, $\mathrm{A}\left(+0.1{ }^{\circ} \mathrm{C}\right)<\mathrm{C}\left(+0.9^{\circ} \mathrm{C}\right), \mathrm{T}\left(+0.9^{\circ} \mathrm{C}\right)<\mathrm{G}$ $\left(+2.7^{\circ} \mathrm{C}\right)$ の順に大きくなっている. また, AP site を含 まない完全相補二重鎖では $T_{\mathrm{m}}$ の増加が見られない $\left(\Delta T_{\mathrm{m}}=+0.2{ }^{\circ} \mathrm{C}, 5^{\prime}-\mathrm{T} \mathrm{CCAGCGCAAC-3} 3^{\prime} / 3^{\prime}\right.$ AGGTCGCGTTG-5')。 以上の結果は，プテリンがグアニ ンと選択的に錯形成することによって AP site に挿入し， その結果, AP site 含有 ODN 二重鎖の熱力学的安定性が 増加したものと解釈できる.

プテリンがグアニン選択性を示すことは，蛍光分光法に よる検討でも得られた．Fig. 7Aに，ODN二重鎖添加前 後におけるプテリンの蛍光スペクトル変化を示す．プテリ ンがグアニンに対してのみ蛍光消光を示し, 他の核酸塩基 には有為なスペクトル変化を示さないことが分かる．440 $\mathrm{nm}$ における蛍光強度変化から, 非線形フィッティングに よりプテリンとグアニンの $1: 1$ 錯形成定数を算出したと

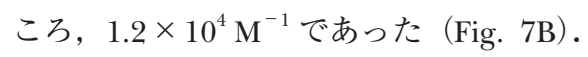

プテリン/グアニンの $1: 1$ 錯体構造については, AMND の場合と同様に，X 線結晶構造解析などを用いた より詳細な検討を待つ必要があるが，Fig. 8 に示すような ワトソンークリック型類似の三点水素結合形成をしている ものと考察している.

\section{5 遺伝子変異蛍光検出への適用}

以上に述べたように，脱塩基部位（AP site）において AMND 及びプテリンは，それぞれシトシン及びグアニン と選択的に錯形成し，かつ蛍光消光を示すしたがって， 


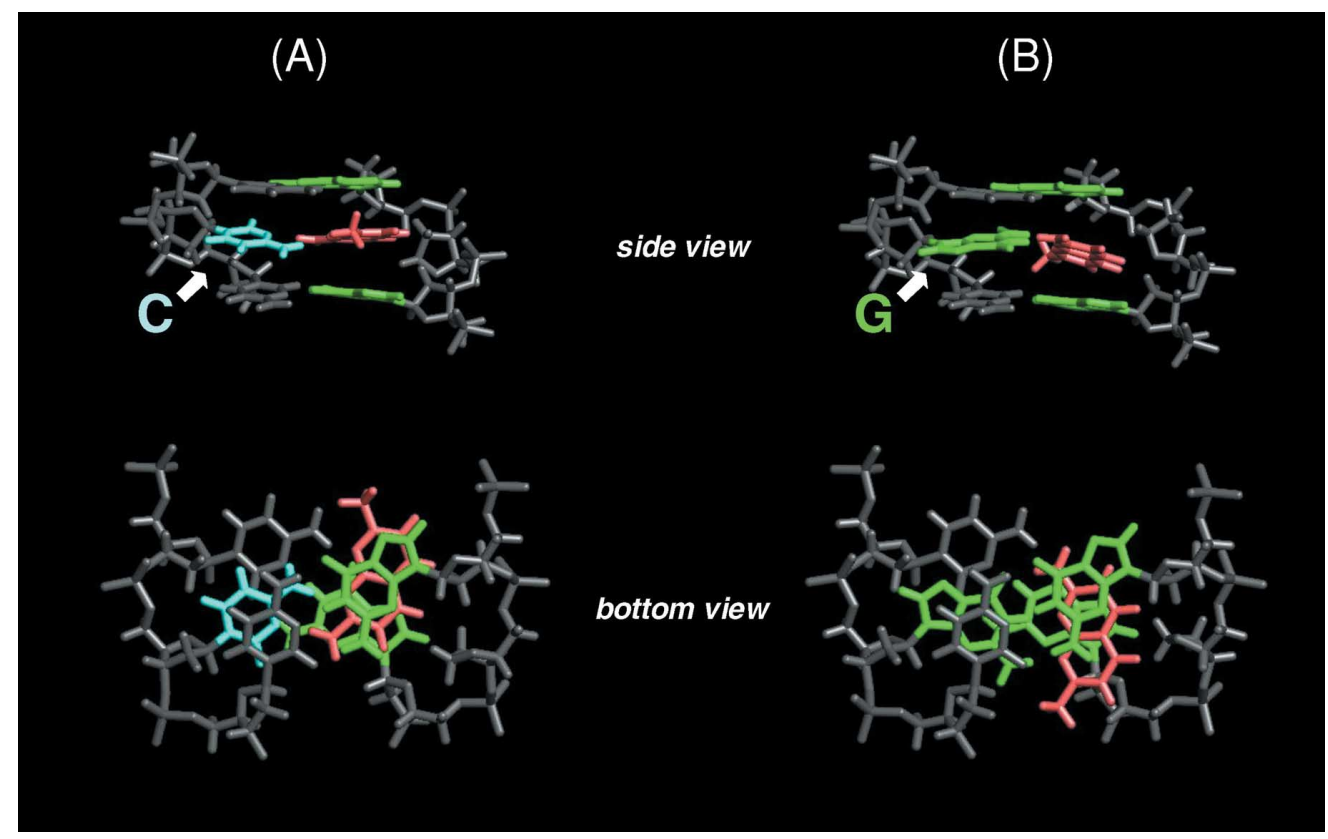

Fig. 6 Proposed binding structures of the complexes between AMND and AP site-containing ODN duplexes (5'-TCCAGXGCAAC-3' /3'-AGGTCYCGTTG-5', $\underline{\mathrm{X}}=\mathrm{dSpacer}, \underline{\mathrm{Y}}=\mathrm{C}, \mathrm{G}$ ), obtained using MacroModel (version 7.2)

The energy minimizations were performed with Amber * force field and GB-SA treatment water for the initial structure of the complex. AMND, cytosine (C) and guanine $(\mathrm{G})$ bases are colored red, blue and green, respectively.

これらの蛍光性リガンドを用いればシトシンあるいはグア ニンが関与する一塩基変異を検出できると期待される。以 下に，実在配列への適用性評価として，がん抑制遺伝子 p53の変異検出を行った結果を述べる.

\section{$5 \cdot 1$ 実在配列（がん抑制遺伝子 p53）中での変異検出} p53 は 393 個のアミノ酸から構成される核タンパク質 で，がん遺伝子治療の標的として最も期待されているがん 抑制遺伝子である ${ }^{29)}$. p53 変異の約 $80 \%$ は点変異であり, ヒトゲノム解析センター (Human Genome Center, HGC $)^{30)}$ のデータベースには，2000を超える点変異が登 録されている。本研究では, AMNDをP P177R $(\mathrm{C} / \mathrm{G}$ 変 異) ${ }^{31)}$ に, プテリンを $\mathrm{R} 175 \mathrm{H}$ (G/A 変異 $)^{32)}$ に適用した. P177R はシトシンがグアニンに変異するもので, これに よりコドン 177 のアミノ酸がプロリン（P）からアルギニ ン（R）に変化する，いわゆるミスセンス変異である。ま た, $\mathrm{R} 175 \mathrm{H}$ は p53 変異のホットスポットの一つであり, コドン 175 のアミノ酸がアルギニン（R）からヒスチジン （H）に変化するグアニン/アデニン変異である．ここで は，標的 ODNを 11-meric ODN として合成したものを用 いた。また, AP site 含有プローブ ODNとしては, 標的 ODN と相補的な, かつ AP site が標的塩基の向側に位置 するように設計したものを用いた。

Fig. 9A に, AMNDをP177R 変異検出に適用した際の
蛍光スペクトル応答を示す．変異型 ODN（5'-CTGCCGCCACC-3'）に対しては蛍光消光が穏やかであるのに対し (spectrum b)，野生型 ODN（5'-CTGCCCCCACC-3'）の存 在下では AMND の蛍光が完全に消光していることが分か る (spectrum c)。この実験条件下では, 肉眼による明り ような $\mathrm{C} / \mathrm{G}$ 変異判定が可能となる (Fig. 9B).

プテリンによる G/A 変異 $(\mathrm{R} 175 \mathrm{H})$ の目視検出も可能 であることが分かった. Fig. 10 に示したように，プテリ ンは変異配列（5'-GAGGCACTGCC-3'）に対して全く蛍光 応答を示さず，野生型（5'-GAGGCGGTGCC-3'）に対して のみ蛍光消光する.また, プテリンは P177R ( $\mathrm{C} / \mathrm{G}$ 変異) 検出にも適用できることから， $\mathrm{C} / \mathrm{G}$ 変異に関しては，プ テリンと AMND の併用により対立遺伝子を識別しうるこ とが分かった。

\section{$5 \cdot 2$ 検出温度}

DNA チップなどのハイブリダイゼーションを利用する 検出法では, その検出過程において精密な温度制御を必要 とする.これは, ハイブリダイゼーションベースの検出法 がパーフェクト/ミスマッチ二重鎖間の熱力学的安定性の 差（つまり $T_{\mathrm{m}}$ の差）を利用しているためで，両者の差を 明確化するための至適プローブの設計や検出条件の設定が 特に重要となる。一方, 本手法では, 標的 DNA/プローブ ODN 間の二重鎖形成が AP site 形成の必須条件であるこ 

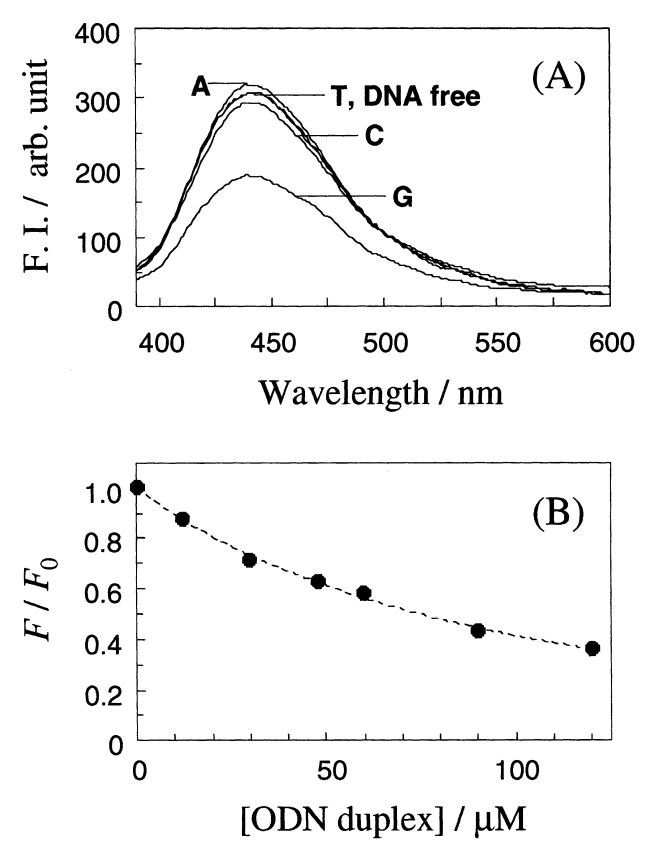

Fig. 7 (A) Fluorescence spectra of pterin $(15 \mu \mathrm{M})$ in the presence of AP site-containing ODN duplexes (60

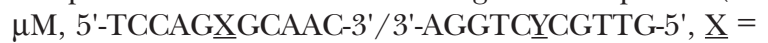
dSpacer, $\underline{Y}=A, C, G, T) . \quad p H=7.0$ adjusted by 10 $\mathrm{mM}$ sodium cacodylate buffer containing $100 \mathrm{mM}$ $\mathrm{NaCl}$ and $1.0 \mathrm{mM}$ EDTA. Excitation wavelength: 360 nm. (B) Fluorescence intensity ratios of pterin at 440 $\mathrm{nm}$ in a titration with AP site-containing ODN duplex (5'-TCCAG $\underline{X G C A A C-3 ' ~ / ~ 3 '-A G G T C G G G T T G-5 ', ~} \underline{X}=$ dSpacer). $\quad F$ and $F_{0}$ denote the fluorescence of pterin $(15 \mu \mathrm{M})$ with and without ODN duplex, respectively. The experimental conditions are identical to those given in Fig. 7A.

と, また, 蛍光性リガンドを用いて塩基選択性を発現させ るために, 検出温度に特に留意することなく塩基変異検出 を行うことができる。

Fig. 11 に，AMNDをP177R 検出に適用した際の蛍光応 答の温度依存性を示す. $20 \sim 50{ }^{\circ} \mathrm{C}$ で明りょうな $\mathrm{G} / \mathrm{C}$ 変 異の蛍光識別が可能であることが分かる. AMND が $50{ }^{\circ} \mathrm{C}$ 以上でその識別機能を失うのは, ODN 二重鎖が解離する ために脱塩基部位空間が形成されないためで，これは AMND 存在下における標的 ODN/脱塩基部位含有プロー ブ $\mathrm{ODN}$ 二重鎖の $T_{\mathrm{m}}$ 值が $50.6^{\circ} \mathrm{C}$ であることとよく合致す る結果である。したがって，本手法では，原理的に検出温 度を $T_{\mathrm{m}}$ 值以下に設定すればよく, 厳密な温度制御やプロ ーブ ODN 設計を必要としないことになる。

\section{6 おわりに}

本研究では, DNA 脱塩基部位（AP site）を分析反応場 として利用することにより，有機小分子による水素結合を 介した核酸塩基認識が達成できることを明らかにした。こ れにより，水素結合形成をべースとする有機小分子の試薬

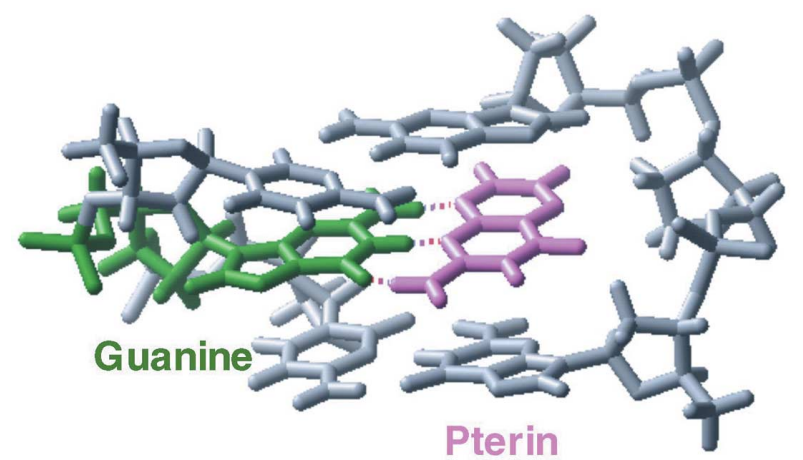<smiles></smiles>

Fig. 8 Possible binding structure of the 1:1 complex between pterin and guanine $(G)$ base

設計が，有機溶媒中のみならず完全水系においても適用し うることが示唆された。また，本系の錯形成モードの大き な特徵は, DNA二重鎖中の核酸塩基とワトソンークリッ ク型類似の錯形成反応ができることにある．この点は，ア クチノマイシン などの DNA 結合試薬の選択性発現が, DNA 二重鎖の副溝面（あるいは主溝面）の認識に基づい ているのとは大きく異なっている。したがって，選択性発 現のための試薬設計がより容易になるばかりでなく, 人工 ヌクレオチドとしてプローブ ODN へ導入する必要もない ため，合成的負担が大幅に軽減される.

更に本研究では, 一塩基多型（SNPs）の蛍光検出法と して本系を展開した．従来の蛍光ラベル化の代わりに蛍光 性有機小分子を利用し，AP site における標的塩基選択的 な核酸塩基認識反応を蛍光シグナル変化として検出する点 に本手法の独創性がある。したがって，本手法では， DNA チップ等で問題となるミスマッチとフルマッチ DNA 二重鎖を識別するための精密な温度制御を必要とせず，更 には検出系に特殊な酵素を用いる必要もない.これらのこ とから, 本手法は安価かつハイスループットな SNPs 検出 法になりうる可能性を秘めている. しかしながら，今後， 本手法を実用レベルへと発展させるには, 幾つかの課題を 克服しなければならない。例えば, PCR 産物の迅速な解 析のためには, リガンドの結合定数を〜 $10^{9} \mathrm{M}^{-1}$ レベルに する必要があり, また, すべての対立遺伝子（アレル）識 別を可能にするためには, 全塩基に対する 4 種類のリガ 

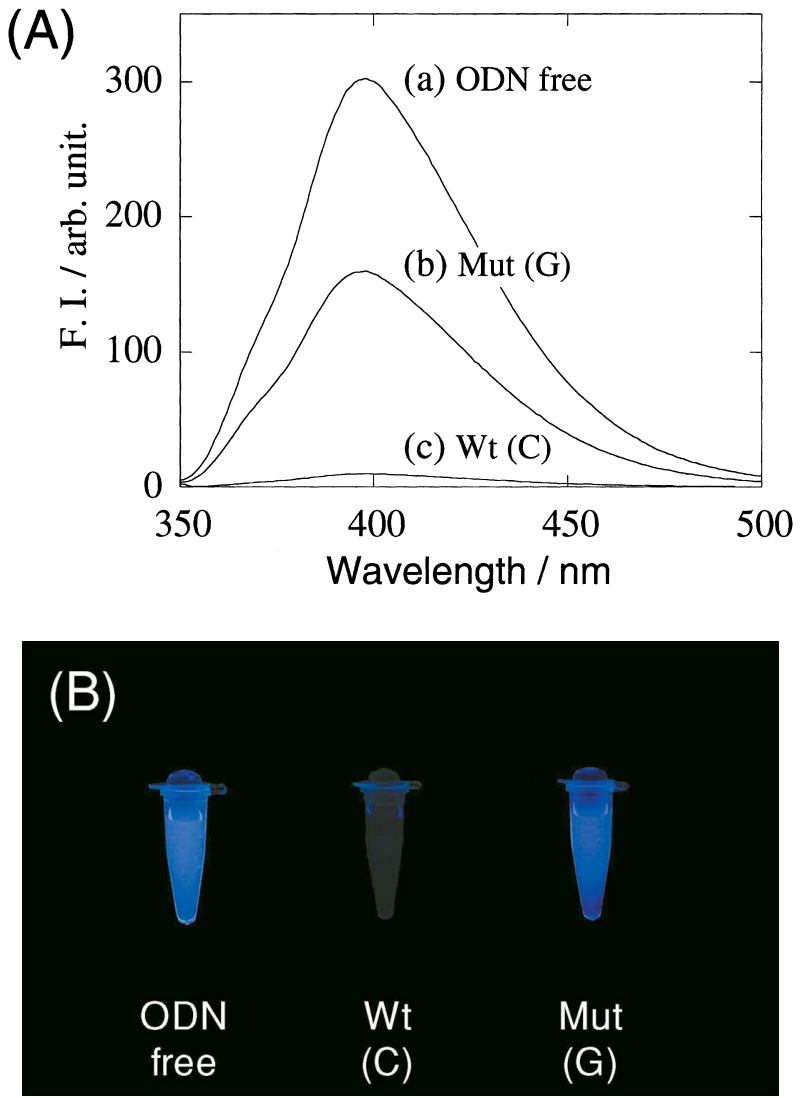

Fig. 9 (A) Effect of AP site-containing ODN duplexes $(60 \mu \mathrm{M}, 5$ '-CTGCCYCCACC-3' / 3'-GACGG $\underline{X G G T G G-~}$ $\left.5^{\prime}, \underline{X}=\mathrm{dSpacer}, \underline{Y}=\mathrm{C}, \mathrm{G}\right)$ on fluorescence spectra of AMND $(30 \mu \mathrm{M})$ : a) ODN duplex free, b) mutation $(\underline{\mathrm{Y}}: \mathrm{G})$, and $\mathrm{c})$ wild type $(\underline{\mathrm{Y}}=\mathrm{C}) . \mathrm{pH}=7.0$ adjusted by $10 \mathrm{mM}$ sodium cacodylate buffer containing 100 $\mathrm{mM} \mathrm{NaCl}$ and $1.0 \mathrm{mM}$ EDTA. Excitation wavelength: $350 \mathrm{~nm}$. (B) Detection of P177R (C/G transversion) based on the changes in fluorescence of AMND. The samples are excited with a UV lamp at $302 \mathrm{~nm}$. The other experimental conditions are identical to those given in Fig. 9A.

\section{ンドを開発する必要がある。}

迅速，簡便かつ安価な SNPs 検出法の開発が，個人個人 に最適化された「テーラーメイド医療」の実現に向けて重 要な研究課題の一つとなっている ${ }^{18) 34) ~ 41)}$. この目標の実 現に向けて本研究を発展させたいと考えている.

本研究の一部は, 文部科学省科学研究費補助金「基盤研究 (A) (2) 」(14204074)，「基盤研究 (B) (2) 」(13554029)，「若手研究 (B) 」 (13740417)，21 世紀 COE プログラム「大分子複雑系未踏化学」, 日本学術振興会「日中科学協力事業共同研究」, 及び「未来開拓 学術研究」によったことを付記し，ここに謝意を表します。
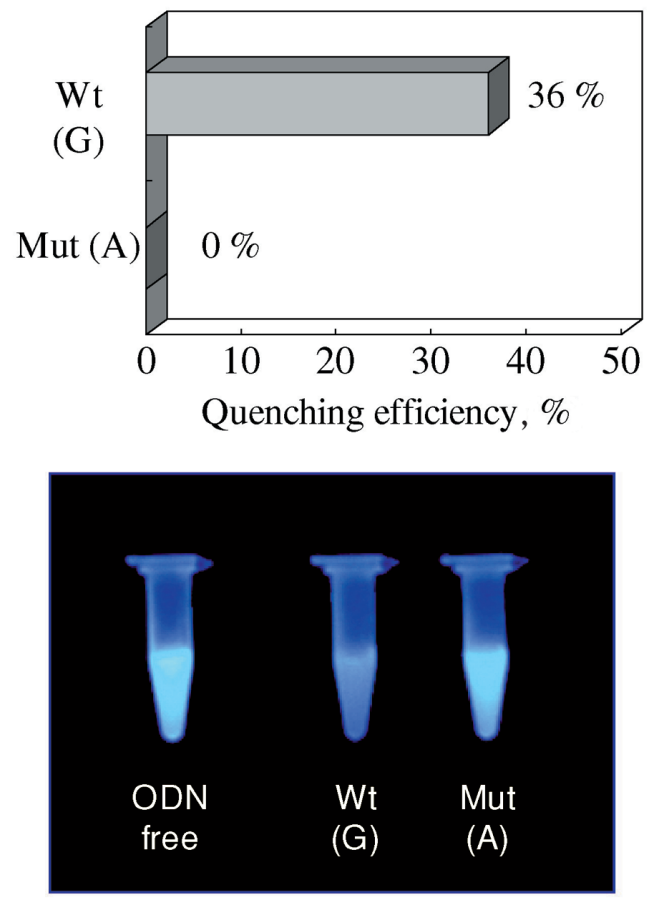

Fig. 10 Fluorescence detection of R175H (G/A transition) based on the changes in fluorescence of pterin [pterin]: $10 \mu \mathrm{M}$; [ODN duplex]: $100 \mu \mathrm{M}$ (5'-GA-

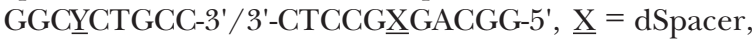
$\underline{Y}=A, G) . \quad p H=7.0$ adjusted by $10 \mathrm{mM}$ sodium cacodylate buffer containing $100 \mathrm{mM} \mathrm{NaCl}$ and 1.0 mM EDTA. Excitation wavelength: $302 \mathrm{~nm}$ with a UV lamp

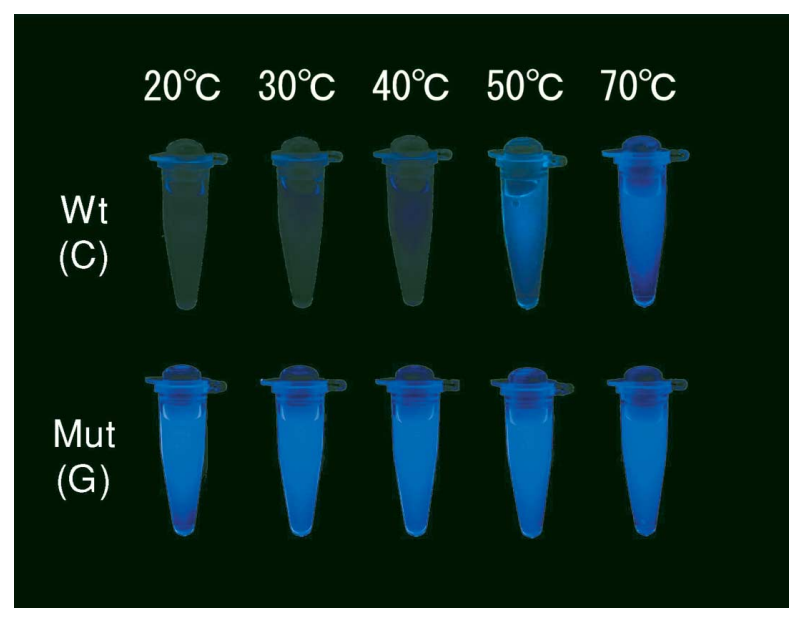

Fig. 11 Effect of temperature on fluorescence of AMND $(30 \mu \mathrm{M})$ in the presence of target ODN duplexes $(60 \mu \mathrm{M}, 5$ '-CTGCCYCCACC-3' /3'-GACGGX XGGTGG$5^{\prime}, \underline{X}=$ dSpacer, $\left.\underline{Y}=\mathrm{C}, \mathrm{G}\right)$

$\mathrm{pH}=7.0$ adjusted by $10 \mathrm{mM}$ sodium cacodylate buffer containing $100 \mathrm{mM} \mathrm{NaCl}$ and $1.0 \mathrm{mM}$ EDTA. Excitation wavelength: $302 \mathrm{~nm}$ with a UV lamp 


\section{文献}

1) J. N. Israelachvili : "Intermolecular \& Surface Forces", p. 122 (1992), (Academic Press, London).

2) A. D. Hamilton, D. Vanengen: J. Am. Chem. Soc., 109, 5035 (1987).

3) J. Rebeck, Jr.: Acc. Chem. Res., 23, 399 (1990).

4) M. Inouye, K. Kim, T. Kitao: J. Am. Chem. Soc., 114, 778 (1992).

5) M. Abe, J. Otsuki, K. Araki: Chem. Lett., 1993, 1541.

6) Y. Kano, M. M. Conn, J. Rebeck, Jr.: J. Am. Chem. Soc., 116, 9411 (1994).

7) W. T. Bell, Z. Hou, C. S. Zimmerman, A. P. Thiessen: Angew. Chem. Int. Ed., 34, 2163 (1995).

8) S. Amemiya, P. Buhlmann, Y. Umezawa: Chem. Commun., 1997, 1027.

9) M. Inouye, M. Takase: Angew. Chem. Int. Ed., 40, 1746 (2001).

10) A. D. Ellington, J. W. Szostak: Nature, 346, 818 (1990).

11) C. Tuerk, L. Gold: Science, 249, 505 (1990).

12) M. Famulok, J. W. Szostak: J. Am. Chem. Soc., 114, 3990 (1992).

13) F. K. Jiang, R. A. Kumar, R. A. Jones, D. Patel: Nature, 382, 183 (1996).

14) K. Nakatani, S. Sando, I. Saito: J. Am. Chem. Soc., 122, 2172 (2000).

15) K. Nakatani, S. Sando, K. Yoshida, I. Saito: Bioorg. Med. Chem. Lett., 11, 335 (2001).

16) K. Nakatani, S. Sando, H. Kumasawa, J. Kikuchi, I. Saito: J. Am. Chem. Soc., 123, 12650 (2001).

17) K. Nakatani, S. Sando, I. Saito: Bioorg. Med. Chem., 9, 2381 (2001).

18) K. Nakatani, S. Sando, I. Saito: Nat. Biotechnol., 19, 51 (2001)

19) K. Yoshimoto, S. Nishizawa, M. Minagawa, N. Teramae: J. Am. Chem. Soc., 125, 8982 (2003).

20) K. Yoshimoto, C.-Y. Xu, S. Nishizawa, T. Haga, H. Satake, N. Teramae: Chem. Commun., 2003, 2960.

21) S. Nishizawa, K. Yoshimoto, T. Seino, C.-Y. Xu, M. Minagawa, H. Satake, A. Tong, N. Teramae:
Talanta, 63, 175 (2004).

22) E. V. Brown: J. Org. Chem., 30, 1607 (1965).

23) J. D. Puglisi, I. Tinoco, Jr.: Meth. Enzymol., 180, 304 (1989).

24) J. A. McDowell, D. H. Turner: Biochemistry, 35, 14077 (1996).

25) B. Demole, L. Harrison: Annu. Rev. Biochem., 63, 915 (1994).

26) K. Nakatani, S. Horie, I. Saito: J. Am. Chem. Soc., 125, 8972 (2003)

27) M. E. Hawkins, W. Pfleiderer, F. M. Balis, D. Porter, J. R. Knutson: Anal. Biochem., 244, 86 (1997).

28) F. Han, B. H. Huynh, H. Shi, B. Lin, Y. Ma: Anal. Chem., 71, 1265 (1999).

29) J. M. Nigro, S. J. Baker, A. C. Preisinger, J. M. Jessup, R. Hostetter, K. Cleary, S. H. Bigner, N. Davidson, S. Baylin, P. Devilee, T. Glover, F. S. Collins, A. Weston, R. Modali, C. C. Harris, B. Vogelstein: Nature, 342, 705 (1989).

30) http://www.hgc.ims.u-tokyo.ac.jp/index.html.

31) N. Nishida, Y. Fukuda, H. Kokuryu, J. Toguchida, D. W. Yandell, M. Ikenega, H. Imura, K. Ishizaki : Cancer Res., 53, 368 (1993).

32) M. S. Morris: Mutation Res., 511, 45 (2002).

33) S. Kamitori, F. Takusagawa: J. Am. Chem. Soc., 116, 4154 (1994)

34) M. Chicurel: Nature, 412, 580 (2001).

35) S. Takenaka, K. Yamashita, M. Takagi, Y. Uto, H. Kondo: Anal. Chem., 72, 1334 (2000).

36) S. Sando, E. T. Kool: J. Am. Chem. Soc., 124, 9686 (2002).

37) A. Okamoto, K. Tainaka, I. Saito: J. Am. Chem. Soc., 125, 7972 (2003).

38) M. Komiyama, S. Ye, X.-G. Liang, Y. Yamamoto, T. Tomita, J.-M. Zhou, H. Aburatani: J. Am. Chem. Soc., 125, 3758 (2003).

39) K. Sato, K. Hosokawa, M. Maeda: J. Am. Chem. Soc., 125, 8102 (2003)

40) H. Aoki, Y. Umezawa: Analyst, 128, 681 (2003).

41) S. Sando, T. Sasaki, K. Kanatani, Y. Aoyama: J. Am. Chem. Soc., 125, 15720 (2003).

分析反応場として DNA 脱塩基部位（AP sites，apurinic/apyrimidinic sites）を利用する水素結合性小分子 による核酸塩基認識，並びにこれを一塩基多型（SNPs， single nucleotide polymorphisms）の蛍光検出に適 用した結果を述べる．脱塩基部位は生体内における塩基除去修復過程の中間体として生成することが知られ ているが，本研究では DNA二重鎖中に意図的に構築し，これを分析反応場として利用する．つまり，標的 塩基を含む一重鎖 DNA と脱塩基部位を有する一重鎖 DNA をハイブリダイゼーションさせることで標的塩 基の向側に疎水場空間を構築させた後，同空間中において水素結合性リガンドとの錯形成を行うというもの である．水素結合性リガンドとして AMND（2-amino-7-methyl-1,8-naphthyridine）及びプテリン（2-amino4-oxopteridine）の錯形成挙動を評価したところ，いずれのリガンドも著しい蛍光消光を伴って，それぞれ シトシン $\left(K_{11}>1.0 \times 10^{6} \mathrm{M}^{-1}\right)$ 及びグアニン $\left(K_{11}=1.2 \times 10^{4} \mathrm{M}^{-1}\right)$ を強力かつ選択的に認識しうることを 見いだした。また，本系をがん抑制遺伝子 p53の一塩基多型の蛍光検出に適用したところ，AMNDによる シトシン/グアニン変異, 及びプテリンによるグアニン/アデニン変異検出が可能であることを明らかにし た. 